6. Historia del Derecho Chileno 

Revista de Estudios Histórico-Jurídicos

[Sección Historia del Derecho Chileno]

XXXV (Valparaíso, Chile, 2013)

[pp. 523 - 545]

\title{
OBSTÁCULOS JURÍDICOS Y CONSULARES A LA INMIGRACIÓN JUdíA DURANTE El GOBIERNO DE ARTURO AlESSANDRI 1932-1938
}

\author{
[Legal and Consular Barriers to Jewish Immigration during \\ Arturo Alessandri's Government, 1932-1938] \\ ENRIQUe Brahm García* \\ Universidad de los Andes, Santiago de Chile \\ Jorge Montes Arrazto***
}

\begin{abstract}
RESUMEN
Cuando en la Alemania nazi se inició un proceso de discriminación y de persecución contra la población judía, que provocó un masivo proceso migratorio, las puertas de la mayoría de los países de Occidente no se abrieron con generosidad para acoger a estos perseguidos. Chile no fue una excepción. Desde muy temprano el gobierno de Arturo Alessandri puso trabas a la inmigración judía, merced a un estatuto jurídico especial, discriminatorio, que se hizo más duro en los años finales de su período presidencial. La revisión de la correspondencia consular en el Archivo del Ministerio de Relaciones Exteriores,
\end{abstract}

\begin{abstract}
When the discrimination and persecution of the Jewish population began in the Nazi Germany, which caused a massive migratory process, the doors of most of the Western countries were not widely open to welcome the persecuted. Chile was no exception. From the beginning, Arturo Alessandri's government placed obstacles to Jewish immigration, due to a special, discriminatory, legal statute, that became stricter over the last years of his presidential term. The review of the consular correspondence in the Archives of the Ministry of Foreign Affairs in Chile reveals that there were also people holding more radical anti-
\end{abstract}

RECIBIDO el 26 de noviembre de 2012 y ACEPTADO el 25 de mayo de 2013.

* Doctor en Derecho por la Universidad de Frankfurt am M. Director del Instituto de Historia de la Universidad de los Andes (Santiago de Chile). Dirección Postal: Universidad de los Andes, San Carlos de Apoquindo 2200, Las Condes, Santiago de Chile. Correo electrónico: ebrahm@uandes.cl

** Licenciado en Historia. Universidad de los Andes. Dirección Postal: Universidad de los Andes, San Carlos de Apoquindo 2200, Santiago de Chile. Correo electrónico: jmontesarra@ gmail.com 
demuestra que también en Chile había quienes sostenían posiciones antisemitas más radicales, a tono con la época.

Palabras Clave

Inmigración judía - AntisemitismoCónsules - Alessandri Palma.
Semitic views, in tune with the times.

\section{KEYWORDS}

Jewish immigration - anti-SemitismConsuls - Alessandri Palma.

\section{INTRODUCCIÓN}

Hoy día, cuando se conoce en detalle el terrible destino sufrido por los judíos europeos que quedaron bajo el dominio de la Alemania nacionalsocialista, los que fueron casi exterminados por la maquinaria de terror hitleriana dirigida por Heinrich Himmler, llama la atención la poca disposición que hubo en el mundo, en general, para recibir a quienes en la década de los treinta buscaban huir de las garras nazis, en un momento en que esto todavía era posible. Debe recordarse que en el "Holocausto" terminarían por ser asesinados cerca de seis millones de judíos, en uno de los genocidios más horripilantes de los que se tenga memoria ${ }^{1}$.

Es evidente que el 30 de enero de 1933, día en el cual Adolfo Hitler fue nombrado canciller de Alemania por el presidente Paul von Hindenburg, nadie podía imaginarse lo que vendría. No cabía duda de que se trataba del líder de un partido que nunca había ocultado su impronta antisemita pero, en un ambiente en el que los prejuicios anti-judíos estaban lejos de ser un monopolio sólo de Alemania, se estaba dispuesto a tolerar algún grado de discriminación contra ellos. Pero había indicios que pudieron haberse observado, si se ponía un poco de atención, que indicaban que el nazismo tenía una postura en extremo radical en estas materias, marcada por un biologismo y darwinismo social extremo, que debían hacer presagiar lo peor, pero no se quiso ver lo evidente.

Por lo demás los mismos judíos alemanes temieron de inmediato lo peor, de tal forma que ya el año 1933, impresionados por el "boykott" decretado contra los negocios judíos y los primeros actos de terror con motivación antisemita, huyeron de Alemania cerca de cuarenta mil, sobre todo personas jóvenes y solteras, judíos con buena situación económica y aquellos que habían sido más activos políticamente $^{2}$. Y a ello se agregarían todo tipo de medidas discriminatorias que los irían excluyendo de la vida pública y privándoles de sus medios de subsistencia ${ }^{3}$. En todo caso la presión bajaría algo en 1934, año durante el cual sólo dejaron Alemania unos 23.000 judíos ${ }^{4}$, que sería el promedio que se mantendría

${ }^{1}$ Hilberg, Raúl La destrucción de los judios europeos (Madrid, Akal, 2005); LONGerich, Peter, Politik der Vernichtung. Eine Gesamtdarstellung der nationalsozialistischen Judenverfolgung, (München, Piper Verlag, 1998); PoHL, Dieter, Holocaust. Die Ursachen-das Geschehen-die Folgen, (Freiburg, Basel, Wien, Herder, 2000).

${ }^{2}$ Longerich, cit. (n. 1) p. 56; y Burleigh, Michael, El Tercer Reich. Una nueva historia, (Madrid, Taurus, 2002), p. 319.

${ }^{3}$ PoHL, cit. (n. 1), pp. 25.ss.

${ }^{4}$ LONGERICH, cit. (n. 1), p. 57. 
durante los años siguientes 5 . Ni ellos mismos se imaginaban los horrores a que iban a estar expuestos.

Si bien durante el año 1935 se promulgarían las famosas "Leyes de Nüremberg", en las cuales, por ejemplo, se prohibían tanto los matrimonios como el contacto sexual de alemanes con judíos, que dieron un mayor sustento jurídico a las políticas discriminatorias ${ }^{6}$, la persecución contra los judíos se haría más intensa sólo una vez que terminaran los Juegos Olímpicos de Berlín de 19367. Ello se manifestaría, en lo inmediato, a través de una serie de medidas que se tomarían para excluir a los judíos de la actividad económica, de la universidad, de la judicatura, del ejercicio de una serie de profesiones liberales, como también restringiendo, hasta casi eliminar, su derecho de propiedad a través de la "arianificación" de sus bienes ${ }^{8}$.

Al mismo tiempo que se iba segregando a la población judía, los nazis los fueron empujando a dejar Alemania. Precisamente la presión económica debía ser un motivo que los impulsara a abandonar su país natal. De hecho entre 1933 y 1941 de los 525.000 judíos que habitaban en Alemania habían salido 278.000; en el caso de Austria y a partir del "Anschluss", serían 120.000 de un total de 220.000 los que encontrarían su salvación en el extranjero?.

El año 1938 -en un momento en que todavía vivían unos 400.000 judíos en territorio alemán ${ }^{10}$-, representaría un importante punto de quiebre en estas materias, al estar marcado por dos hechos fundamentales: la anexión de Austria y la "noche de los cristales rotos"11. Para Abraham Barkai el año 1938 sería el "Schicksalsjahr" de los judíos alemanes ${ }^{12}$. En efecto, a partir del mes de marzo de 1938, particularmente en Viena, los nazis austríacos impondrían un ambiente de "progrom" contra los judíos y luego se replicarían las medidas persecutorias y discriminatorias que ya se habían introducido en Alemania, aunque a un ritmo mucho más rápido. Se haría realidad en meses lo que al otro lado de la frontera se había concretado en años. Más todavía, se pondría en funcionamiento un programa de emigración forzosa liderado por Adolf Eichmann, quién en base a esta experiencia sería más adelante el encargado de llevar a los judíos a la muerte en los campos de exterminio ${ }^{13}$.

Luego de la "Reichskristallnacht", orgía de destrucción y muerte contra la población judía alemana, que terminaría con decenas de muertos, miles de judíos llevados a campos de concentración, cientos de sinagogas incendiadas y

${ }^{5}$ POHL, cit. (n. 1), p. 30.

${ }^{6}$ LONGERICH, cit. (n. 1), pp. 102. ss.

${ }^{7}$ LONGERICH, cit. (n. 1), pp 118 ss.

${ }^{8}$ LONGERICH, cit. (n. 1), pp. 118 ss.

9 Brahm, Enrique, Hitler y la Segunda Guerra Mundial (Santiago de Chile, Editorial Universitaria, 1999), p. 159.

${ }^{10}$ Heim, Sussane - Meyer, Beate - Nicosia, Francis R. (editores), "Wer bleibt, opfert seine Jahre, vielleicht sein Leben”. Deutsche Juden 1938-1941, (Göttingen, Wallstein, 2010), p. 8.

${ }^{11}$ Heim - Meyer - Nicosia, cit. (n. 10), pp. 103. ss. y 11. ss.; Burleigh, cit. (n. 2), pp. 361 ss.

${ }^{12}$ Heim - Meyer - Nicosia, cit. (n. 10), p. 10.

${ }^{13}$ PoHL, cit. (n. 1), pp. 30 ss. 
miles de negocios destruidos, a la población de origen israelita de Alemania se le haría evidente que no les quedaba más que tratar de escapar. Ello no sería fácil porque a esas alturas más de la mitad de la población judía era mayor de 50 años y la cuarta parte de ella carecía absolutamente de recursos y dependía de ayudas sociales para vivir ${ }^{14}$. Además la guerra se acercaba a pasos agigantados y con ello, cómo Hitler lo anunciaría muy pronto, la persecución a los judíos alcanzaría sus formas extremas.

En medio de esas difíciles circunstancias, en el mes de julio de 1938, se reunían en Evian-les-Bains, junto al lago de Ginebra, representantes de 32 países, entre ellos Chile, para buscar una solución al problema de la creciente inmigración judía. Pero los resultados no fueron auspiciosos. Las naciones representadas no estaban muy dispuestas a abrir completamente sus fronteras para recibir a quienes escapaban del nazismo ${ }^{15}$. De hecho, pese a que durante el año 193840.000 judíos dejaron Alemania, la política inmigratoria estaba llegando a sus límites. Cada vez eran más los estados que se negaban a recibir refugiados. Suiza cerró sus fronteras para los judíos en marzo de 1939, mientras que Gran Bretaña hacía prácticamente lo mismo con Palestina ${ }^{16}$. Esta situación es lo que llevaría a decir al presidente estadounidense Bill Clinton al inaugurar el Museo del Holocausto en Washington, el año 1993 que "antes de que la guerra estallara ya estaban cerradas las puertas de la libertad"17. De hecho los mismos norteamericanos mantuvieron en vigencia durante estos años una ley de inmigración de 1924 particularmente restrictiva y que se interpretaría todavía con más rigor desde los inicios de la gran depresión. A lo que debe agregarse el hecho de que muchos funcionarios consulares americanos relacionaban a los judíos con el bolchevismo, por lo que pondrían a éstos particulares trabas para su ingreso en los Estados Unidos. Existía un sistema de cuotas, las que nunca se ampliaron. Los judíos copaban la disponible para Alemania, que era bastante grande, aunque siempre quedaban muchos fuera. En cambio para los países de Europa oriental, de los que provenían muchos judíos, las cuotas eran muy pequeñas. ¿Por qué los estadounidenses no modificaron la ley para favorecer a quienes huían de la persecución nazi? De partida, ellos probablemente no se imaginaron lo extrema que era la situación. Por otra parte el presidente Roosevelt, que buscaba llevar a los Estados Unidos a la guerra, no quería que eso se entendiera como condicionado por los intereses de los judíos americanos. Además los norteamericanos estaban lejos de dejar atrás la recesión -de hecho el "peak" de esta se alcanzaría en los años 1937/1938- por lo que ni en el Congreso ni en el pueblo estadounidense había un ambiente favorable para abrir más sus fronteras a la inmigración extranjera ${ }^{18}$.

${ }^{14}$ Heim - MeYer - Nicosia, cit. (n. 10), p. 11.

${ }^{15}$ Burleigh, cit. (n. 2), p. 351; FriedläNDER, Saul, El Tercer Reich y los judios (1933-1939). Los años de persecución (Barcelona, Galaxia Gutenberg - Círculo de Lectores, 2009), pp. 340 ss.

${ }^{16}$ Pohl, cit. (n. 1), p. 32; FriedläNder, cit. (n. 15), pp. 408 ss.

${ }_{17}$ Novick, Peter, Nach der Holocaust. Der Umgang mit dem Massenmord, (Stuttgart München, DVA, 1999), p. 70.

${ }^{18}$ Novick, cit. (n. 17), pp. 72 ss. 
Es en este contexto en el que debe ubicarse la política practicada por el gobierno chileno en materia de inmigración judía durante el segundo período de Arturo Alessandri. Debe considerarse al respecto que los primeros años del mismo coincidirían con aquella etapa en que la presión por abandonar Alemania todavía no sería tan extrema y en la que se buscaba ser recibidos en países europeos más cercanos. La cuestión en cambio se complicaría hacia fines de su período presidencial -años 1937 y 1938- en los que se radicalizó la política nazi y, cómo recién se ha señalado, se fueron cerrando muchas puertas a la inmigración judía. De hecho de los 13.000 judíos que llegarían a Chile, más de las tres cuartas partes los harían entre noviembre de 1938 y fines de $1939^{19}$.

\section{La política inmigratoria Del gobierno de Arturo Alessandri}

Tradicionalmente Chile ha sido un país muy abierto a la inmigración extranjera. Más todavía, durante el siglo XIX los gobiernos nacionales, cualquiera fuere su color político, habían ido aprobando una serie de normas por las que se buscaba atraer extranjeros industriosos que vinieran a dar un fuerte impulso al desarrollo y al progreso del país ${ }^{20}$. Entre esos inmigrantes, desde fines del siglo XIX, empezarían a llegar algunos judíos, flujo que crecería en las primeras décadas del siglo siguiente como consecuencia de la difícil situación que les tocaría vivir en Europa Oriental ${ }^{21}$. Según señala Moshé Nes-El, hacia 1930 vivían en Chile 3.697 judíos; y agrega que: "La colectividad judía chilena estaba establecida en Chile desde fines del siglo diecinueve y principios del siglo veinte y se componía principalmente de judíos ashkenazíes, de Rusia, Polonia y Rumania y de sefardíes de Macedonia, Salónica, islas griegas, Turquía y Norte de Africa"22.

La situación general de la inmigración extranjera sufriría un cambio radical a partir de la gran depresión de 1929. En efecto, Chile fue de los países más afectados por la misma, lo que entre otras cosas se tradujo en que las cifras de cesantía alcanzaran cotas extremas ${ }^{23}$. Como consecuencia de ello los gobiernos nacionales se sintieron en la obligación de salir en defensa del trabajador nacional ante una posible competencia extranjero, estableciendo restricciones a la inmigración. Ya en la "Memoria" del Ministerio de Relaciones Exteriores para el año 1932 se señalaba: "La situación económica del país ha obligado a restringir la inmigración de la mano de obra extranjera que viene a competir con el obrero nacional. Este se

${ }^{19}$ WojaK, Irmtrud, Exil in Chile. Die deutsch-jüdische und politische Emigration während des Nationalsozialismus 1933-1945, (Berlin, Metropol, 1994), p. 47.

20 Brahm García, Enrique, Manuel Montt y la colonización de Llanquihue, en Manuel Montt, AA. VV., Educador, legislador, gobernante y magistrado. Estudios en conmemoración del bicentenario de su nacimiento (1809-2009), (Santiago de Chile, Fundación Manuel Montt, 2009), II, pp. 127 ss.

${ }^{21}$ Nes-EL, Moshé, Estudios sobre el judaismo latinoamericano (2a edición, Buenos Aires Jerusalem, Ediciones Ultra, 1987), p. 111.

${ }^{22}$ Nes-EL, Moshé, Estudios sobre el judaísmo chileno (Tel Aviv, Ediciones Revista de Oriente y Occidente, 2009), p. 51.

${ }^{23}$ VIAL, Gonzalo, Historia de Chile (1891-1973), IV: La dictadura de Ibáñez (1925-1931), (Santiago, Editorial Fundación, 1996), pp. 452. ss. 
encuentra en desventajosa situación, debido a la paralización momentánea de fábricas y centros productivos. Se han dado a los cónsules facultades discrecionales de acuerdo con directivas previas del Departamento (Consular), a fin de seleccionar y limitar el número de extranjeros que vienen en busca de trabajo a Chile./ Estas medidas se mantendrán mientras se solucione nuestra situación interna./ Se ha seguido en esta materia la política adoptada por la mayoría de los paises extranjeros. Se persigue proteger en lo posible al nacional, sin dejar por eso de fomentar la entrada de elementos útiles para el pais" 24 .

La nueva política se hizo efectiva de inmediato a través del envío a los cónsules chilenos en el extranjero, de parte del Ministerio de Relaciones Exteriores, de una "Circular confidencial" de 27 de octubre de 1932, que instruía a estos en el sentido de ser más restrictivos en el otorgamiento de visas, debido a los efectos que había tenido la crisis en el mercado laboral chileno ${ }^{25}$. Un año más tarde, el Decreto supremo $N^{\circ} 4072$ precisaría los alcances de la nueva política inmigratoria. En su artículo 21 se señalaba que "los Cónsules chilenos no visarán pasaportes de individuos que no tengan una industria, profesión, aptitudes o recursos que les permitan vivir en Chile sin constituir una carga social'; mientras en el siguiente se establecía que los mismos funcionarios podrían "negar la visación del pasaporte de individuos que a juicio del Cónsul, sean inadaptables a la legislación y costumbres de Chile, o que en concepto del mismo Cónsul, dadas las condiciones y situación actual de este país, no tengan posibilidades de ganarse la vida en él"26.

Cuando entraba en vigencia el decreto recién citado el problema migratorio comenzaba a tomar un cariz muy distinto, desde el momento en que en Alemania había sido nombrado canciller Adolfo Hitler el 30 de enero de 1933 y empezaba a concretarse una política de discriminación y persecución de la población judía en Alemania ${ }^{27}$, de la que en Chile se tomaría conocimiento de inmediato. Por ejemplo, a raíz del "boicot" contra los judíos organizado por el partido nacionalsocialista, primer acto público y abierto de persecución contra la población alemana de origen semita, se discutió en la Cámara de Diputados de Chile un voto de protesta frente a esos hechos, presentado por el diputado Edmundo Fuenzalida el 4 de abril de 1933. A él se opuso el diputado Arturo Gardeweg, quién, aún cuando condenó el antisemitismo, estimaba que las noticias llegadas desde Alemania eran exageraciones de la prensa y de organizaciones judías ${ }^{28}$. En La Semana Internacional, revista publicada en Valparaíso, de 10 de abril de 1933, se señalaba en un artículo titulado El avispero judio en Alemania: "Mala primavera para los hijos de Israel germánicos. Las iras de la nueva Alemania han caido duramente sobre ellos, levantando una tempestad que está barriendo los 'ghettos' mosaicos"29.

Cómo se ha señalado en la introducción, a partir de ese momento tomaría fuerza una creciente corriente migratoria de judíos que buscarían escapar del nazismo,

\footnotetext{
${ }^{24}$ Nes-EL, Estudios, cit. (n. 21), p. 112.

${ }^{25}$ WOJAK, cit. (n. 19), p. 80.

${ }^{26}$ WOJAK, cit. (n. 19), p. 80.

${ }^{27}$ BraHm, Hitler, cit. (n. 9), pp. 51 ss. y 151. ss.

${ }^{28}$ Nes-EL, Estudios, cit. (n. 22), p. 54.

${ }^{29}$ La Semana Internacional, 10 de abril de 1933, 2.
} 
situación que incidiría de inmediato en la política migratoria chilena. En efecto, ello llevaría a que desde el gobierno y específicamente a través del Ministerio de Relaciones Exteriores y de su departamento consular se empezara a regular de una forma especial la inmigración judía. Ya en el mes de diciembre del año 1933 se habrían impuesto algunas restricciones para el ingreso de ese tipo de inmigrantes, como se desprende del contenido de una nota enviada por la Cancillería al cónsul de Chile en Hamburgo, en orden a que reprendiera al cónsul en Berlín por no haber respetado este las circulares del ministerio relativas al otorgamiento de visas a extranjeros de determinadas razas, particularmente israelitas. De 18 visas, el cónsul en Berlín habría concedido 14 a "individuos de esta raza", lo que demostraría su desconocimiento de la normativa vigente ${ }^{30}$.

En la misma línea, el año 1934 se recibió una petición del gobierno español en orden a que Chile aceptara recibir 2000 refugiados judíos alemanes, a lo que el Ministerio de Relaciones Exteriores se negó, aduciendo otra vez los problemas económicos que tenía el país en ese momento ${ }^{31}$.

Mientras tanto, y en forma paralela, se habría llegado informalmente a un acuerdo entre el gobierno de Arturo Alessandri y la Sociedad de Protección al Inmigrante Israelita, filial de la HICEM, institución judía internacional que tenía esos mismos fines, en virtud del cual se establecía una cuota de 50 familias judías que podrían radicarse en Chile anualmente, seleccionadas por la sociedad antes mencionada. Este acuerdo se mantendría en vigencia hasta fines del gobierno de Alessandri ${ }^{32}$.

Por lo demás la política migratoria del gobierno chileno, sobre todo en relación a los judíos, seguiría siendo objeto de discusión en las cámaras. Así, por ejemplo, en el mes de agosto de 1936, el ministro de Relaciones Exteriores de Alessandri, Miguel Cruchaga, se veía obligado a dar explicaciones ante los parlamentarios en orden a que no estaba prohibida la entrada de los israelitas perseguidos en Europa -"sobre lo que no debo pronunciarme"-. Sólo se exigía a los inmigrantes, cualquiera fuera su origen, que fueran "adaptables" a las circunstancias chilenas. El Canciller aprovechaba de refrendar lo que, por lo menos oficialmente, venía siendo la política del gobierno en estas materias: "En la actualidad, el Gobierno y el Congreso estudian la dictación de medidas tendientes a favorecer y mejorar la situación de lo que se ha dado en llamar 'clase media'. Contraría tal propósito la ilimitada admisión de extranjeros [...] y aún aquellos cuya ocupación en el pais de origen era el cultivo de la tierra o el trabajo manual en las industrias, prefieren dedicarse aqui al pequeño comercio intermediario [...] Esta circunstancia contribuye a determinar el exceso de competencia entre pequeños comerciantes, en ciertos grupos profesionales [...] como es bien sabido, también, el hecho de que en la capital y sobre todo en provincias, el pequeño comercio está casi integramente en manos de extranjeros [...] (Chile siempre ha ofrecido asilo a víctimas de persecución). Pero el gobierno tiene la obligación de

${ }^{30}$ WOJAK, cit. (n. 19), p. 81.

${ }^{31}$ Nes-EL, Estudios, cit. (n. 22), p. 56.

${ }^{32}$ Nes-El, Estudios, cit. (n. 22), p. 56; WoJAK, cit. (n. 19), p. 88; y Fermandois, Joaquín, Abismo y cimiento. Gustavo Ross y las Relaciones entre Chile y Estados Unidos 1932-1938 (Santiago, Ediciones Universidad Católica de Chile, 1997), p. 236. 
reglamentar conforme a los altos intereses nacionales, económicos, políticos y sociales" 33 . Pese a la apariencia neutra de la intervención ministerial y a los argumentos de tipo económico desarrollados, estaba implícita en ella la referencia a los judíos, desde el momento en que el estereotipo del mismo era el del comerciante o especulador y eran en esos momentos víctimas de persecución.

La cuestión volvería a ser discutida a propósito de la "Conferencia de Evián", a la que llamó el presidente estadounidense Franklin Delano Roosevelt en el mes de julio de 1938, al agudizarse el problema de los refugiados tras la anexión de Austria por Alemania ${ }^{34}$, y en la que Chile estuvo representado por el político demócrata Fernando García Oldini. Este se cuidó de comprometerse a nada muy concreto, fuera de condenar en términos más bien generales la política nazi ${ }^{35}$. Seguía así las instrucciones que había recibido del ministro de Relaciones Exteriores de Chile, José Ramón Gutiérrez Alliende, quien en nota de 4 de julio de 1938 señalaba lo siguiente: "Por aéreo van instrucciones conferencia Evian. En resumen: a) Evitar todo compromiso formal, b) Tener presente escasa receptividad Chile y disposiciones vigentes sobre limitación entrada israelitas para evitar inmigración excesiva de una sola clase y sobre preferencias productores frente a intermediarios y profesionales; c) No aceptar sino pasaportes regulares de Gobiernos. d) No aceptamos pasaportes Nansen ni similares; e) Consultar en cada caso de importancia siquiera relativa" ${ }^{36}$.

En ese contexto el senador Maximiano Errázuriz aprovechaba la ocasión para expresar de una forma muy completa lo que eran en esos momentos los "prejuicios anti-judios" ${ }^{37}$ tradicionales, dominantes en ciertos sectores de la sociedad chilena. Luego de hacer referencia al problema "de los judios que han sido perseguidos últimamente en Alemania y en Austria, y que buscan otros paises donde ir a radicarse" y al vapor "Imperial", en el que habrían llegado a Chile un número importante de judíos, señalaba: "Yo no sé si sea oportuno, en estos momentos, abrir tan ampliamente las puertas a la inmigración extranjera y, sobre todo, en términos generales, a cualquier clase de inmigrantes", ello porque vendrían a competir con los obreros y comerciantes chilenos. El énfasis se ponía en estos últimos, porque en el país ya serían demasiado los "intermediarios", mientras que lo que se necesitaba eran productores y, sobre todo, agricultores. "Desgraciadamente" -agregaba Errázuriz,- "los judios no son agricultores; son eminentemente comerciantes, de modo que, sin duda, vendrán a competir y se convertirán en nuevos intermediarios, ya excesivamente abundantes, como he dicho, entre nosotros". Además se darían con ellos problemas de asimilación. Luego, en la parte más dura de su intervención, decía: "Hablando de los judios, señor Presidente, debo declarar que siempre he hecho profesión de combatir el antisemitismo. Yo me eduqué en Europa, en paises que existía antisemitismo, y siempre me pareció que esto era algo duro y cruel, siempre me horrorizaron los 'progroms' de Polonia y las persecuciones de hebreos en Ucrania,

${ }^{33}$ Citado por Fermandois, cit. (n. 32), p. 236.

${ }^{34}$ LONGERICH, cit. (n. 1), p. 187.

${ }^{35}$ Ness-EL, Estudios, cit. (n. 22), p. 58.

${ }^{36}$ Archivo del Ministerio de Relaciones Exteriores (= AMRE), vol. 1708.

${ }^{37}$ Fermandois, Joaquín, Mundo y fin de mundo. Chile en la politica mundial 1900-2004, (Santiago, Ediciones Universidad Católica de Chile, 2004), p. 157. 
Rumania y otros paises de Europa. Condeno de todo corazón el cruel tratamiento que hoy reciben en Alemania [...]. Pero no hay duda, señor Presidente -y este es el punto principal que quiero dejar establecido, después de haber estudiado y haber conversado mucho al respecto-, no hay duda digo, que son los judios mismos quienes se encargan de crear problemas ahi donde previamente no los hay. Últimamente conversaba en Hungría con personas prominentes de allá y les preguntaba ¿por qué tienen ustedes esta inquina en contra de los judios? ¿Por qué no les tienden la mano y ven manera de entenderse con ellos? Y me respondian: 'Cómo se ve que usted vive en un país donde no existe este problema. Aqui son una fuerte minoría, una minoría muy apreciable, pero han conseguido tal preponderancia financiera, que abarcan todos los negocios, ocupan todos los altos cargos, controlan la banca, en fin, no dejan nada para los demás de modo que si nos vemos obligados a mirarlos con antipatía, es porque ellos mismos nos colocan en esta situación"”. Terminaba pidiendo al gobierno "que restrinja en lo posible la entrada de israelitas a nuestro pais, y que se atenga la cuota fijada; pero como entiendo que la cuota de este año ha sido excedida, sería de desear que no se diera, de aquí hasta el 31 de diciembre próximo, ningún permiso más" 38 .

Las palabras de Maximiano Errázuriz darían lugar a un intenso debate, en el que varios senadores, como Oscar Schnake y Rafael Luis Gumucio, lo rebatirían con fuerza. Este último, por ejemplo, diría, que "en este momento el pueblo de Alemania sufre la más terrible y atroz tiranía, tiranía comparable sólo con la de Rusia. En esa noble y hoy desgraciada nación sufren persecuciones los católicos, los judios y los protestantes", de ahí que creía que era “un deber de humanidad” el “dar generosa acogida a los perseguidos que vengan a pedir asilo en nuestra tierra, que es tierra de libertad". Concluía pidiendo al gobierno que abriera "ampliamente la puerta a toda persona de buenos antecedentes que haya sido expulsada de Alemania" ${ }^{39}$.

Esta discusión deja en evidencia también que, a esas alturas, el conocimiento que había en Chile de lo que estaba ocurriendo en Alemania con la población judía, era bastante completo. Por ejemplo, en un informe del año 1936 de la Embajada de Chile en Alemania, contenido en una "Memoria" titulada "Situación política en Alemania 1935" 40 , se afirmaba: "Los hechos más relevantes de la política interna son los que se refieren a las campañas de depuración de la raza alemana, como dicen, y que se traducen en una persecución a los judios, que hace recordar crueldades dignas de la Edad Media. Alemanes de siglos caen bajo las estrictas disposiciones de la ley por el delito de no ser arios. Son expulsados del pais por medios indirectos que hacen imposible su vida en él y deben abandonarlo junto con la mayor parte de sus fortunas que se quedan a beneficio del Estado" ${ }^{41}$.

De estas cuestiones se hacía también eco la prensa. La Hora recogía el 6 de agosto de 1938 una nota publicada en El Diario de La Serena, donde se decía: "El nacionalismo cerrado, extremado hasta el racismo, o sea a la eliminación de un pais de los extranjeros de raiz étnica distinta, lo condena el Pontifice, y no puede ser menos,

\footnotetext{
${ }^{38}$ Sesiones del Senado, ordinaria de 12 de julio de 1938, I, pp. 875 ss.

39 Sesiones del Senado, ordinaria de 12 de julio de 1938, I, pp. 875. ss.

${ }^{40}$ Que había sido el año de la aprobación de las leyes de Nüremberg. BRAHM, Hitler, cit.

${ }^{41}$ Citado por WoJAK, cit. (n. 19), p. 85.
} (n. 9), p. 158. 
ya que quien acordó amar a los enemigos, no iba a mirar impasible que se destierre a quienes ni siquiera son enemigos, sino que sólo tienen en su contra el pertenecer a una raza distinta a la de los grupos mayoritarios de un pais" 42.

Naturalmente que particular repercusión tendría en la prensa chilena la "noche de los cristales rotos" de noviembre de 1938 -cuando ya se acercaba a su fin el gobierno de Alessandri-, hecho que marcaría un punto de quiebre en la política racial del régimen nacionalsocialista, mostrando de manera abierta al mundo la verdadera cara del nazismo ${ }^{43}$. En su editorial del 14 de noviembre, titulado Barbarie, se señalaba en La Hora: "Pasado el primer instante de estupor producido en el mundo por los trágicos sucesos ocurridos en Alemania la noche del jueves último, en que millares de hogares y de establecimientos comerciales e industriales de judios fueron asaltados y destruidos, y sus dueños conducidos a campos de concentración, el espiritu de humanidad y de elevación que anida en todo ser, se siente estremecido por estos horrores que no encuentran parangón sino que en los días obscuros de la Edad Media" ${ }^{4}$.

Mucho más cauto se mostraba en cambio, ElMercurio. Si bien a propósito del mismo hecho afirmaba que: "toda doctrina de racismo llevada a extremos absolutos tendrá que estrellarse siempre con el sentimiento de la libertad y la igualdad entre los hombres que ya se ha hecho carne de los pueblos organizados bajo la civilización cristiano occidental'; pero a reglón seguido limitaba algo los alcances de esa crítica al sostener que "las razones que han inducido a las autoridades del 'Reich' a adoptar medidas para expulsar de su territorio a los miembros de esa raza no son discutidas, porque pertenecen al derecho que cada nación tiene de dictar sus leyes y administrar sus intereses como mejor le plazca" ${ }^{45}$.

\section{UN ESTATUTO JURÍDICO ESPECIAL PARA LA INMIGRACIÓN JUDÍA}

Al momento de iniciarse el segundo período de gobierno del presidente Arturo Alessandri Palma, se encontraba vigente el Reglamento de Pasaportes de 20 de octubre de $1931^{46}$. De acuerdo a lo dispuesto en esa normativa, cualquier extranjero podía entrar al país cumpliendo únicamente con el requisito de contar con un pasaporte debidamente visado por el consulado chileno competente. Por otra parte, los cónsules podían "negar la visación del pasaporte de individuos que a juicio del Cónsul sean inadaptables a la legislación y costumbres de Chile o que en concepto del mismo Cónsul y dadas las condiciones y situación actual de este país, no tengan posibilidad de ganarse la vida en é l' (artículo 23). Además estaban autorizados para negar o postergar la visación de un pasaporte "hasta consultar a sus superiores", en los casos en los que tuvieran dudas o no contaran con los antecedentes suficientes para resolver (artículo 24).

\footnotetext{
${ }^{42}$ La Hora, 6 de agosto de 1938.

${ }^{43}$ Burleigh, cit. (n. 2), pp. 356 ss.

${ }^{44}$ La Hora, 14 de noviembre de 1938.

${ }^{45}$ El Mercurio, 22 de noviembre de 1938.

46 Publicado en el Diario Oficial de 26 de octubre de 1931.
} 
Este reglamento sería reemplazado luego por el de 25 de enero de $1937^{47}$, que mantendría las normas antes reseñadas ${ }^{48}$, pero agregaría algunas exigencias adicionales para la concesión de los visados. Así es cómo en el artículo 21 se señalaba: "Los cónsules chilenos se negarán terminantemente a visar pasaportes de individuos que no tengan una industria, profesión, aptitudes o recursos que les permitan vivir en Chile sin constituir una carga social o que se nieguen a firmar la declaración a que se refiere el inciso $2^{\circ}$ del artículo $1^{\circ}$ ('Todo extranjero que desee venir el país deberá comprometerse, por escrito, ante el Cónsul chileno respectivo, a no participar durante su permanencia en Chile, en la política interna ni en los actos que puedan inferir molestias a Gobiernos con los cuales se mantienen relaciones amistosas)" 49 .

De la lectura de ambos reglamentos quedaba claro que, por regla general, la visación de pasaportes de extranjeros que quisieran viajar a Chile era una atribución que correspondía exclusivamente a los cónsules chilenos en el exterior y que no había ninguna norma especial relativa a la población judía. De ahí que ya resulte cuestionable la fijación de cuotas para los inmigrantes israelitas que se habría acordado informalmente con la HICEM, a la que antes se ha hecho referencia.

Más todavía, el claro tenor de las disposiciones reglamentarias antes citadas terminaría por ser dejado en parte sin efecto a través de una serie de "Circulares confidenciales”, emanadas del Departamento Consular del Ministerio de Relaciones Exteriores. En efecto, después de la Nº 2 de 17 de febrero de 1937 por medio de la cual se comunicaba a los cónsules la entrada en vigencia del nuevo reglamenta y se acompañaban ejemplares del Diario Oficial en que éste había sido publicado ${ }^{50}$, se les hacía llegar la $\mathrm{N}^{\circ} 3$ de julio de $1937^{51}$, que introducía cambios importantes en los procedimientos vigentes. Ello ocurría luego de que Miguel Cruchaga Tocornal dejara su cargo de Ministro de Relaciones Exteriores en manos de José Ramón Gutierrez Alliende, quien habría adoptado "una línea aún más estricta que su predecesor" 52 , en relación a la inmigración judía.

La nueva circular se presentaba como una forma de reglamentación provisoria, hasta que se sentaran las bases "de una politica inmigratoria que contemple las efec-

${ }^{47}$ Publicado en el Diario Oficial de 12 de febrero de 1937.

${ }^{48}$ En los artículos 23 y 24, aunque ahora quedarían recogidas en los artículos 22 y 23 del nuevo reglamento.

${ }^{49}$ Artículo 21. En el inciso $2^{\circ}$, se agregaba: "Tampoco visarán dichos consulados pasaportes de individuos que sufran de enfermedades transmisibles, agudas o crónicas, constitucionales o locales, o de vicios orgánicos incurables; de mujeres menores de edad que no viajen a cargo de personas honorables y con permiso de sus padres o guardadores; de hombres que no lean ni escriban a lo menos en su propio idioma; de condenados o procesados por delitos comunes que la Ley chilena califique de crimenes o simples delitos; de prófugos de la justicia por delitos no politicos; de expulsados de Chile $o$ de otro país por la autoridad competente; de rameras, sus explotadores o acompañantes; de ebrios consuetudinarios, toxicómanos y sus explotadores; de individuos que sostengan, propaguen y enseñen la alteración del orden social o politico por medios violentos e ilegales; de los que vivan de actividades no permitidas en Chile o se dediquen al espionaje; de los mendigos y vagos; $y$ de aquellos que por instrucciones especiales del Ministerio de Relaciones Exteriores se les haya prohibido la entrada".

${ }^{50}$ Circular confidencial $\mathrm{N}^{\circ} 2$ de 17 de febrero de 1937, AMRE, vol. 17.

${ }^{51}$ Circular confidencial $N^{\circ} 3$ de 3 de julio de 1937, AMRE, vol. 17.

${ }^{52}$ Nes-EL, Estudios, cit. (n. 22), p. 58. Gutiérrez Alliende asumió su cargo el 24 de marzo de 1937. 
tivas necesidades de nuestro pais" 53 . Ella se esbozaba en el "Mensaje" presidencial de Arturo Alessandri de 1938, cuando decía: "En cuanto a Chile estamos abiertos a que la inmigración se acreciente cada día dando para ello toda clase de facilidades. Pero también creo oportuno dejar testimonio de la resolución del Gobierno de la República de no admitir que los conflictos de orden politico o la difusión de credoso ideologías que agitan la opinión pública en otros pueblos, lleguen a Chile y den motivo para actividades que encuadran mal dentro del concepto que tenemos de nuestra soberanía y del respeto de nuestras leyes. Asi como recomiendo [...] el respeto a los Jefes de Estado extranjeros y a las instituciones de otros países, así también confio en que no se hará necesaria la intervención del Gobierno sobre actividades extranjeras que en Chile no podríamos tolerar" ${ }^{4}$. La idea era llegar a establecer cuotas de inmigración, facilitar la llegada de "elementos productores" y de quienes fueran "asimilables a nuestro medio social". Más todavía, "se contemplarán los factores biológicos que interesan al mejoramiento de nuestra población”. Mientras tanto, y ante la necesidad de resolver los problemas urgentes inmigratorios, "derivados de las actuales circunstancias políticas europeas”, se daban a los cónsules una serie de instrucciones en lo que a la visación de pasaportes se refería. Entre ellas cabe destacar aquella que ordenaba "poner trabas a elementos que no sean convenientes al país", entre los que se encontrarían los "comerciantes" y "profesionales, como médicos, abogados, etc." [I,d)]. Particular importancia reviste lo que se contemplaba en el número III de la Circular, donde se señalaba: "Queda entregada exclusivamente al Ministerio -quien autorizará en cada caso a los cónsules- la facultad de autorizar visaciones de pasaportes a los individuos de las siguientes nacionalidades:/ Rusos, estones, lituanos, letones, polacos, rumanos, búlgaros, albaneses, griegos, turcos, sirios, palestinos y libaneses./ Asimismo, es facultad exclusiva del Ministerio autorizar visaciones de pasaportes de individuos de razas de color".

Esta norma ya llamaba la atención por la forma como se discriminaba a una serie de naciones y "razas". Pero todavía faltaba el $N^{\circ} \mathrm{IV}$, donde se estipulaba lo siguiente: "Respecto a los israelitas, de acuerdo con la resolución tomada por este Ministerio, sólo podrán visar sus pasaportes los Consulados Generales de Hamburgo, Paris y Génova, con orden expresa del Departamento (Consular) para cada caso particular./ Si hubiere lugar a dudas sobre el origen racial de otros inmigrantes procedentes de Alemania, los interesados en venir a Chile tendrán que acreditarlo con certificados oficiales, debiendo darse preferencia a quienes no tengan ascendientes inmediatos israelitas".

En la práctica esto significaba que, cómo lo reconocería más adelante la Comi-

${ }^{53}$ Primer párrafo de la Circular. Seguramente se hacía referencia a un proyecto de ley tendiente a reglamentar y regular la inmigración que el gobierno enviaría al Congreso en el mes de agosto de 1938 y que nunca se aprobaría. El proyecto se justificaba en el gran flujo migratorio que se estaba produciendo en el mundo como consecuencia de los "cambios sustanciales en su estructura politica o conflictos internos de prolongadas y dolorosas consecuencias" que afectaban a una serie de países. Ellos provocaban grandes desplazamientos humanos, de los cuales había que captar los buenos elementos, pero frenar el ingreso de los "menos deseables", para lo cual se proponía un sistema de cuotas. Sesiones del Senado de 22 de agosto de 1938, 1531 ss. Cfr. Sesiones del Senado de 7 de junio de 1939, I, 309.

${ }^{54}$ Citado por Fermandois, Abismo, cit. (n. 32), p. 235. 
sión Especial designada para dictaminar acerca de la Acusación de la Cámara de Diputados en contra del ex Ministro de Relaciones Exteriores del Frente Popular Abraham Ortega, de hecho existía un "Estatuto especial" para los inmigrantes israelitas ${ }^{55}$.

Finalmente cabe señalar que las normas a que se ha hecho referencia causarían cierta confusión en el cuerpo consular, lo que llevaría a que en el mes de diciembre de 1937 se enviara a los cónsules la Circular N²4, titulada Aclaraciones sobre visación de pasaportes, en la que entre otras cosas se señalaba: "Lamentablemente se ha podido constatar que algunos Cónsules no han comprendido el espiritu del reglamento de Pasaportes. Las múltiples consultas sin objeto práctico, las visaciones evidentemente erróneas, las negativas infundadas, etc., han llevado al convencimiento de que contrariamente a lo ordenado, en vez de dar facilidades a la buena inmigración, le han puesto toda clase de dificultades". Más adelante añadía: "En consecuencia, tratándose de extranjeros de reconocido prestigio o de inmigrantes de condiciones físicas, morales y raciales inmejorables, no deben darles una visación "en visita", "en viaje comercial" o "sujeta a contrato", [...] sino una visación definitiva" 56 .

Un ejemplo de los problemas generados por la aplicación de la Circular $\mathrm{N}^{\circ}$ 3 puede ser el planteado por la negación del cónsul en Belgrado para visar los pasaportes de algunos ciudadanos yugoeslavos. Al respecto desde el Departamento Consular se hacía saber a los cónsules involucrados en el problema que las instrucciones contenidas en esa Circular estaban orientadas a "no permitir la venida al pais de elementos que no vengan a producir riqueza, ya sean estos comerciantes $o$ profesionales. Tampoco se permite la venida de israelitas, ni de personas de razas de color". Respecto a los judíos agregaba que para los que desearan viajar a Chile se había establecido "una cuota, de acuerdo con lo que se ha juzgado conveniente para la demografía chilena, y para ser incluido en ella los interesados deben presentarse a la HICEM con el objeto de que esta institución, bajo su garantía, haga a este Ministerio la solicitud que corresponda" 57 .

\section{El papel de los cónsules y del Departamento Consular}

A partir del momento en el que se hicieron llegar a los cónsules de Chile en Europa las instrucciones contenidas en la Circular confidencial $\mathrm{N}^{\circ} 3$, pasarían a jugar un rol clave en todo el proceso relativo a la inmigración de la población judía que buscaba escapar de las persecuciones desatadas contra ellos por el régi-

${ }^{55}$ Sesiones del Senado, ordinaria de 26 de junio de 1940, p. 609. La misma Comisión señalaba a continuación (p. 610): "Se comprueba, pues, con el texto de esta nota confidencial, que después de haberse dictado el Reglamento Consular de 25 de enero de 1937, el Ministerio de Relaciones Exteriores por medio de una nota privó a los Cónsules de los derechos que les otorgaba aquel Reglamento en orden a la visación de pasaportes de judios quedando entregada exclusivamente al Ministerio, y en cada caso particular, la facultad que la reglamentación consular otorgaba a aquellos".

${ }^{56}$ Circular $\mathrm{N}^{\circ} 24$, Aclaraciones sobre visación de Pasaportes de diciembre de 1937, AMRE, vol. 17.

${ }^{57}$ Carta del Departamento Consular de 22 de julio de 1937, AMRE, vol. 1179. 
men nacionalsocialista de Adolfo Hitler, los mismos cónsules y el Departamento Consular dentro del Ministerio de Relaciones Exteriores de Chile.

Figura clave en el funcionamiento del estatuto jurídico especial antes reseñado, lo sería el jefe del Departamento Consular del Ministerio de Relaciones Exteriores, Carlos Errázuriz Ovalle. Al corresponderle aplicar una política gubernamental muy discutida, estará en medio de una serie de controversias. Así tendrá tanto fieles defensores ${ }^{58}$, cómo también importantes contradictores ${ }^{59}$.

De lo que no cabe ninguna duda es que sería un aplicador estricto de las normas que apuntaban a restringir al máximo el ingreso de población de origen judío a Chile. Algunos ejemplos. En nota confidencial de 11 de mayo de 1938 dirigida al cónsul general de Chile en Yugoeslavia, el que había enviado al Ministerio el listado de pasaportes visado por ese Consulado durante el mes de marzo, Carlos Errázuriz señalaba que el cónsul no había "considerado para nada las instrucciones impartidas por Circular confidencial $N^{\circ} 3$, de junio del año próximo pasado" en la que se disponía la "absoluta prohibición de visar pasaportes a individuos de raza judía, salvo especial autorización de este Ministerio". Concluía la nota con la amenaza de que "si en el futuro se repite esta falta al reglamento de visación de pasaportes, será considerada como falta grave y se verá obligado el Departamento a tener que aplicar las más severas sanciones" $"$.

Un caso similar se encuentra en una nota confidencial dirigida al cónsul de Chile en Rotterdam, a propósito de la visación de un pasaporte de un ciudadano judío alemán en febrero de 1938, en la que Carlos Errázuriz le recordaba al funcionario chileno en Holanda que les estaba "estrictamente prohibido a los cónsules" efectuar visaciones "sin la previa autorización de este Ministerio"61. Y en otra que tenía como destinatario final al cónsul en Copenhague, el jefe del Departamento

${ }^{58}$ En el "Informe" de la Comisión investigadora formada a raíz de la acusación constitucional de que sería objeto el ministro de Relaciones Exteriores del Frente Popular, Abraham Ortega, se decía: "En esa fecha, mediados de 1937, el Departamento Consular autorizaba las visaciones de israelitas. Su jefe, don Carlos Errázuriz Ovalle, aplicó con serenidad la política gubernativa. Odiosidades fueron el galardón de su celo". El Diario Ilustrado de 22 de enero de 1940.

${ }^{59}$ El embajador en Gran Bretaña, Agustín Edwards, se quejaba ante el ministro José Ramón Gutiérrez en carta de 13 de agosto de 1938, de que Errázuriz Ovalle tenía un criterio muy estrecho en materia de inmigración. Como consecuencia de ello se estaría abusando de "gentes desamparadas o necesarias para el país, en nombre de una especie de comunión espiritual con los que han estado enarbolando el estandarte de la persecución religiosa y de raza". Ello sin perjuicio de que a continuación se mostrara de acuerdo con la "idea de impedir que la persecución racial que ha estallado en Europa provoque un desborde de emigración hacia Chile, que vaya a perturbar todo nuestro sistema social y económico". FermandoIs, Abismo y cimiento, cit. (n. 32), p. 238.

${ }^{60}$ Nota confidencial $N^{\circ} 45$ del Departamento Consular al señor cónsul de Chile en Yugoeslavia de 11 de mayo de 1938. AMRE, vol. 1647 A. Los pasaportes objetados eran los siguientes: "visación $N^{\circ} 13 / 12$, señor Erich Blumenthal, raza judia, se le otorgó visación ordinaria; visación $N^{\circ} 14 / 13$, señora Elisabeth Danielsohn de Blumenthal, raza judia, se le otorgó visación ordinaria; visación $N^{\circ} 23 / 20$, señor Jakov Ergas, raza judia, se le otorgó visación ordinaria; visación ( $N^{\circ}$ ilegible), señor Pinhas Ergas, de raza judía, se le otorgó visación ordinaria; visación $N^{\circ} 23 / 20$, señora Karina Navon de Ergas y tres hijos, de raza judia se le otorgó visación ordinaria; y visación $N^{\circ} 24 / 21$, señora Luna Farafji de Ergas, raza judía, se le otorgó visación ordinaria”.

${ }^{61}$ Nota confidencial $N^{\circ} 51$ de 19 de Mayo de 1938, AMRE, vol. 1647 A. Cfr. nota confidencial $\mathrm{N}^{\circ} 83$ de 13 de agosto de 1938, AMRE, vol. 1647a. 
Consular concluía de manera enfática: "con respecto a la visación de pasaportes US. debe recordar al señor Cónsul que sólo está facultado para otorgarlos a ciudadanos daneses. En otros casos deberá siempre consultar al Consulado General' ${ }^{2}$.

En otra situación, sin embargo, ante la queja del cónsul de Chile en Berlín, Artemio Zañartu, en el sentido de que el Ministerio estaría patrocinando "la idea absurda de negarle visación a los judios cuando se trate de gente útil y honorable", Carlos Errázuriz respondía en términos duros: "Quiero hacerle saber-por si lo ignora-, que toda persona de esta raza que signifique una ventaja para Chile no encuentra inconvenientes para obtener la autorización de su visación por parte del Ministerio, lo cual hace improcedentes influencias de ministros o intervención de $S$. E. para el caso" "63.

Pero Carlos Errázuriz Ovalle no se limitaría tan sólo a ser un funcionario estricto, preocupado del exacto cumplimiento de las leyes y reglamentos y, en particular, de las circulares emanadas del Departamento Consular, sino que se descubren en él evidentes prejuicios anti judíos, los que van incluso más allá de lo que era normal en esa época en ciertos sectores de la sociedad chilena. Ellos se descubren con particular claridad en la correspondencia que mantuvo durante el año 1938 con algunos de los cónsules chilenos con los que coincidía en esa actitud.

Sin cerrarse de forma absoluta a la llegada de inmigrantes judíos buscaba someterlos a parámetros muchísimo más exigentes que los que se pedían a cualquier emigrante europeo occidental. Por ejemplo, en carta dirigida al cónsul general de Chile en Hamburgo, Cesáreo Alvarez de la Rivera - uno de los cónsules chilenos más duros en su actitud ante los judíos, como se tendrá oportunidad de ver-, insistía en la necesidad de velar porque fueran "agricultores de verdad (no sastres o decoradores transformados ocasionalmente en cultivadores de las tierras, y que son lobos vestidos de piel de cordero) o industriales de verdad y no fabricantes de artículos de galalite o peleteros, [...]", o "capitalistas de verdadera capacidad y que vengan a hacer inversiones, no para explotarnos con su potencia financiera". Luego agregaba: "Carniceros, sastres, empleados técnicos en radio, fabricantes de fantasías, peleteros y profesionales como ingenieros, masajistas, ortopédicos, etc., no deben venir si son judios, pues no hacen más que quitar el trabajo que bien podrian efectuar los chilenos o los buenos extranjeros" 64 .

$\mathrm{Al}$ mes siguiente, y en respuesta al mismo cónsul en Hamburgo que le había

${ }^{62}$ Nota de 23 de noviembre de 1938, AMRE, vol. 1647 A.

${ }^{63}$ Carta de 6 de octubre de 1938, AMRE, vol. 1708.

${ }^{64}$ Carta de 7 de junio de 1938, AMRE, vol. 1708. Más adelante agregaba: "Para los informes sobre las solicitudes de judios me parecería conveniente establecer una norma general que abarcaría: 1) Aspecto personal (impresión)./2) Verdadera profesión (clasificar como comerciantes a todos los que no son productores de riqueza y en ningún caso aceptar "transformaciones" de última hora./3) Salud (citar el informe médico y expresar la opinión personal que se ha formado en caso de que se haya presentado al Consulado, si no lo ha hecho dejarlo también establecido, como para no hacerse responsable de lo que dicen los papeles)./ 4) Honorabilidad (dejar constancia del documento que lo acredita y el verdadero valor que tiene el testimonio)./ 5) Moralidad (citar el certificado que sí lo acredita y apreciación sobre su valor)./6) Capital (monto y forma en que lo transferiria a Chile)/ 7) Observaciones (principalmente opinión sobre la posibilidad de que este individuo sea de utilidad 
hecho algunos comentarios en torno a la comunicación antes citada, Carlos Errázuriz le escribía diciendo: "Mucho me agrada dejar constancia del empeño que $U d$. demuestra en acoger todas aquellas indicaciones que signifiquen limitar lo más posible la inmigración de individuos de esta raza (judios) que-expulsados ya del viejo mundo- tienden ahora sus redes a las naciones jóvenes de América, llenas de posibilidades". Luego lo felicitaba por encontrarse entre aquellos "que no quieren ver a su pais y sus riquezas en manos del judaismo internacional", para terminar con un párrafo decidor y muy personal: "Nosotros aqui por nuestra parte hacemos todo lo posible por atajar a aquellos que tratan de meterse por la ventana. Claro está que esta tarea es un poco ingrata y muchas veces no conseguimos nada, pero en fin, es nuestro deber" ${ }^{\prime \prime}$.

Una aproximación indirecta a la posición sustentada por Carlos Errázuriz en torno a los judíos, se encuentra en una carta que le dirigió el cónsul de Chile en Génova, Jorge Barriga Errázuriz, con el cual mantenía una relación muy cercana, el 3 de enero de 1938, de la que lamentablemente no se cuenta con la respuesta del jefe del Departamento Consular, que consta se dio el día 28 del mismo mes. En el párrafo medular de la misma el cónsul señalaba: "He seguido siempre con atención tu lucha anti-semita. Me imagino lo que habrás sudado en esa contienda contra viento y marea. Tu esfuerzo en ese sentido ha sido y es altamente digno. iNo hay peor plaga que el judio! ;Es el excremento de la humanidad! Son preferibles a ellos los hotentotes y los canibales. Cuando esa epidemia se filtra en un país, es como la filoxera para la vid. Poco a poco van ocupando puestos de importancia, se insinúan en el comercio, en la banca, en la industria y en la administración pública. Cuando han ocupado todos los puestos estratégicos [...] jes la catástrofe para los nativos! Todo se derrumba entonces como por encantamiento. Desaparece el amor patrio, la dignidad nacional, el culto del pasado, la hombría de bien. Son algo asi como el quinto jinete del Apocalipsis. ;Guay del pueblo que cae bajo el trabajo hipócrita de esas cucarachas! Tu bien conoces la simpatía que les tengo a los judios, de manera que puedes juzgar de la sinceridad de estas lineas. Desde que Hitler los echó de Alemania, ese país respira; igual cosa sucede en Austria y Hungría. Ahora en Rumania, el nuevo Gobierno nacionalista los está expulsando en masa; tenían contagiado a este pais, ankilosado (sic), casi destruido. En Italia, los dignos hijos de Israel, están pasando las de Cain. ¿Que se vayan a la m. ellos y sus descendientes!"66.

Naturalmente, los anteriores no son dichos de Carlos Errázuriz, pero la confianza y el tono coloquial con que se le transmiten -luego de que en el primer párrafo de la carta se le ha preguntado por su familia y por la posibilidad de que

para la economía chilena tanto demográfica como productora)./8) Opinión resultante (conveniente, indiferente, inconveniente)".

${ }^{65}$ Carta de 16 de julio de 1938, AMRE, vol. 1703 A.

${ }^{66}$ Carta de 3 de enero de 1938, AMRE, vol. 1708. En el párrafo siguiente agregaba: "Nosotros los chilenos difícilmente nos damos cuenta de ciertos grandes problemas sociales, que son ya viejos en Europa. Cuando aqui se resuelven en cualquier forma, ya sea bruscamente o despacio, el eco de la solución llega hasta nosotros en forma de crónica periodística y nada más. La vida fácil que llevamos hasta hace diez años, todavía pesa sobre nosotros. Ahora empezamos a abrir los ojos; pero con todo, estoy seguro que son bien pocos los que pesan y miden el peligro judio, por ejemplo. Te debes encontrar bien sólo en esa lucha". 
viajen a Europa-, dan pie para pensar que en buena parte debían ser compartidos por el jefe del Departamento Consular.

La carta recién citada deja en evidencia también que, dentro del cuerpo consular chileno, había quienes adherían de forma plena a la política restrictiva a la inmigración judía que se impulsaba desde el Ministerio del Exterior. Las opiniones extremas sustentadas por el cónsul en Génova, no son un hecho aislado dentro de la correspondencia consular de esos años. Al contrario, daba la impresión que había quienes, sobre la base de los tradicionales prejuicios antijudíos que existían desde antiguo en ciertos sectores de la sociedad chilena, tendían ahora a mimetizarse, por lo menos en parte, con el nuevo antisemitismo que se había impuesto en Alemania y empezaba a difundirse por Europa ${ }^{67}$.

Un caso muy conocido y que en su momento generó una gran polémica en la prensa nacional se originó a raíz de la publicación en un diario de París y bajo el título Una confesión cínica, una carta del cónsul General de Chile, Alfredo Viel, dirigida a "Monsieur Ivel P.", reproducida luego por los diarios chilenos, en que este funcionario explicaba los requisitos exigidos por Chile para acoger inmigrantes extranjeros. La discusión se generó a partir de la última frase de ese texto en la que el Cónsul, luego de haber detallado una serie de trámites burocráticos con los que debía cumplirse, concluía diciendo: "debo agregarle, que si Ud. es judío, será inútil que Ud. haga estas diligencias" ${ }^{68}$. Ante esto el Ministerio de Relaciones Exteriores se vio obligado a explicitar su política inmigratoria ${ }^{69}$. Al respecto y demostrando el cabal conocimiento que se tenía en Chile de los sucesos europeos, en la declaración pública del ministerio se partía con la constatación de que "en diversos paises se expulsa o se obliga a emigrar a los israelitas". A continuación se esgrimían las razones económicas clásicas que se venían utilizando para limitar la inmigración, las que, siendo en apariencia generales, calzaban a la perfección con los perjuicios tradicionales que afectaban a los judíos. En efecto, se señalaba por el Ministerio que "a fin de evitar la venida al país de personas que no pueden encontrar aquí trabajo adecuado a sus habilidades, o que ejercen oficios, profesiones o actividades tales como las del comercio minorista, algunas profesiones liberales, etc. que están lejos de ser factores de incremento de la riqueza" y "sin ningún prejuicio de raza", se había visto en la necesidad de regular-como hacían "todos los paises del mundo"- "la entrada de emigrantes forzosos". Luego pasaba a

${ }^{67}$ Por ejemplo, se usaba en comunicaciones oficiales la típica terminología usada por el régimen nacionalsocialista. Es así el caso de la distinción entre "israelitas" y "arios” para distinguir a quienes se había otorgado visa para viajar a Chile. Cfr. carta del consulado de Chile en Berlín de 11 de enero de 1940, AMRE, vol. 1796; carta del consulado de Chile en Amberes de 11 de enero de 1940, AMRE, vol. 1796; carta del consulado de Chile en Viena de 21 de febrero de 1939, AMRE, vol. 1711 A.

${ }^{68}$ El Mercurio, 5 de agosto de 1938; La Nación, 8 de agosto de 1938.

${ }^{69}$ La que estaba siendo cuestionada. Por ejemplo un editorial de El Mercurio de 5 de agosto de 1938, titulado ¿Política racial en Chile?, ante la sospecha de que se hubiera procedido en ese caso según criterios raciales, señalaba: "Esto debe aclararse. No podemos aceptar ni aún la sospecha de que se haya deslizado en nuestro servicio consular una práctica absurda, una doctrina contraria al interés elemental de todos los paises americanos que son paises de inmigración y contraria a la tradición liberal que ha inspirado las leyes y las prácticas de esta República". 
hacer referencia al acuerdo al que se había llegado con la HICEM, con el que durante el período de poco más de un año que estaba en vigencia, se había "autorizado la entrada de casi el doble del número de familias israelitas" que se había convenido con esa institución. Con estos antecedentes llegaba a la conclusión de que "el cónsul de Chile en París tuvo razón al afirmar que si la persona que deseaba venir a Chile era israelita, era inútil que se dirigiera directamente al Ministerio. Pudo agregar, tal vez, que debía hacerlo al Comité de Protección de Israelitas en Santiago"70.

Otro caso relativamente conocido y extremo es el del Cónsul en Praga, Gonzalo Montt Rivas, quién representaba a Chile en la capital de Checoslovaquia, a esas alturas el único país de esa zona de Europa en que todavía subsistía un régimen democrático. En todo caso la presión que ejercía sobre los checos la Alemania nazi se iría acrecentando, tomando como pretexto los problemas que tendrían los alemanes de los "Sudeten", hasta terminar con la desintegración de ese estado multinacional durante el año 1938 y la ocupación por Alemania del territorio checo en marzo de 1939, constituyéndose el "Protectorado de Bohemia y Moravia" que quedaría unido al "Reich" alemán"1. En ese contexto, y poco antes de que empezaran a precipitarse los acontecimientos antes señalados, en carta de 14 de octubre de 1937 dirigida al Ministerio de Relaciones Exteriores, Gonzalo Montt señalaba: "Casi el total de los cónsules honorarios de estos países pertenece a la colectividad judia; estos cargos dan oportunidad para muchos negocios y también negociados, que explotan con su característica habilidad los hijos de Israel. Últimamente el tráfico ilícito de armas ha dado oportunidad para comprobar, una vez más, que son los cónsules judios los que tienen participación principal en estas actividades. No creo que US necesite mayores datos al respecto, ya que bien conoce la modalidad de esta raza"72.

Un año después y con el territorio checo ya convertido en Protectorado alemán, el cónsul chileno en Praga tenía palabras todavía más duras contra la población judía. Luego de describir, desde una perspectiva muy favorable a Alemania, lo que había sido el proceso de desintegración del estado checoslovaco y de cómo la división de éste -la constitución de una Eslovaquia autónoma y la entrega de territorios a Polonia y Hungría-, había generado serios problemas para el desplazamiento de la población, concluía con el siguiente párrafo: "La situación de los miles de judios que viven aqui se hace imposible: los echan de todas partes y seguramente se tomarán medidas aqui análogas a las de Alemania para acabar con ellos"73. En todo caso no es fácil imaginar lo que entendía Montt por el “acabar con ellos", en un momento en que todavía faltaba algún tiempo para que se pusiera a funcionar la maquinaria burocrática que terminaría por dar forma al "Holocausto". De lo que no cabe duda, en cambio, es de sus extremos prejuicios anti judíos, de lo que es una prueba evidente el texto de una carta que había enviado al Ministerio el

${ }^{70}$ El Mercurio de 5 de agosto de 1938.

${ }^{71}$ BraHM, Hitler, cit. (n. 9), pp. 105 ss.

72 Carta de 14 de octubre de 1937, AMRE, vol. 3118, citado por Farías, Víctor, Los nazis en Chile (Santiago, Editorial Planeta Chilena, 2003), II, p. 81.

${ }^{73}$ Carta de 9 de octubre de 1938, AMRE, vol. 4002, citado por Farías, cit. (n. 72), p. 82. 
27 de julio de 1938, haciendo ver el peligro que significaban para Chile las visas "en tránsito" a Bolivia que se estaban otorgando por los representantes de ese gobierno. Señalaba allí: "Van a Bolivia, porque otros países no los reciben, elementos sumamente peligrosos para nuestro pais, que tratarán de quedarse en Chile antes de llegar a Bolivia o de volver a Chile una vez de que se den cuenta de que allí tienen más porvenir que en Bolivia. Se trata en casi su totalidad de judios comerciantes, que nada aportan al progreso de los pueblos en que viven, que no tienen otra patria que el dinero y que son vehículo de comunismo y otras ideas disolventes, que predican pero no practican. Por otra parte son sumamente feos y en su eventual cruce con las razas aborigenes resultarian verdaderos 'partos de los montes' ridiculus mus (sic!). Es pues necesario que nuestras autoridades de Arica y Antofagasta controlen debidamente el tránsito de esta gente, impidiendo que se queden en Chile [...]"74.

Un tono similar es el que caracteriza las comunicaciones del cónsul de Chile en Zürich, Raúl Cousiño. En carta personal dirigida a Carlos Errázuriz Ovalle de 15 de octubre de 1938, le hacía saber que "Suiza, y sobre todo los cantones de Zürich y Basilea están absolutamente invadidos por estos asquerosos. No menos de 80 llegan diariamente al Consulado llorando por una visa para Chile, cuando no insolentes y valiéndose de cuanto subterfugio es imaginable para poder engañar, lo que aun no han conseguido". Luego alertaba también sobre las facilidades que daba Bolivia a la inmigración judía y el peligro que esto significaba para Chile, por lo que les daba a estos sólo visación en tránsito por cuatro días. Concluía diciendo: "Bueno Carlos, como bien se que tu eres con tanta razón el peor cuchillo contra estos canallas, te pido que el Ministerio oficie llamando la atención a las Policías de Arica y otros puertos a fin de que cumplan fielmente con las anotaciones anotadas en cada pasaporte. Nuestra Patria te lo agradecerá algún dia"75.

Particularmente representativo de este sector del cuerpo consular que parecía simpatizar con las políticas discriminatorias de la población judía que estaba aplicando de manera cada vez más radical el régimen nazi, es el cónsul general de Chile en Hamburgo, Cesáreo Álvarez de la Rivera. Tanta era su cercanía con las autoridades alemanas del momento que en una cena organizada por el Instituto Ibero-Americano de Hamburgo, a la que asistieron como invitados especiales los miembros del gabinete de Hitler Heinrich Lammers, jefe de la Casa Presidencial, y Lutz Graf Schwerin von Krosigk, Ministro de Hacienda, sería condecorado por esa institución junto con el ministro de Relaciones Exteriores alemán Joachim von Ribbentrop ${ }^{76}$.

Sobre todo en su correspondencia con el jefe del Departamento Consular, Carlos Errázuriz Ovalle, Álvarez de la Rivera tendría juicios particularmente duros

${ }^{74}$ Citado por Farías, Víctor, Los nazis en Chile (Barcelona, Editorial Seix Barral S.A., 2000), p. 188.

${ }^{75}$ Carta de 15 de octubre de 1938, AMRE, vol. 1708. Carlos Errázuriz contestaba el 27 de octubre señalando: "Mi primera palabra debe ser de agradecimiento por tus informaciones, que revelan un vivo deseo por servir a nuestra patria impidiendo la entrada de individuos que constituyen un verdadero peligro". AMRE, vol. 1708.

${ }^{76}$ Carta de 5 de abril de 1939 de la Embajada de Chile en Alemania, AMRE, vol. 1729 A. 
hacia la población de origen israelita que buscaba dejar Alemania. Por ejemplo, en carta de 15 de marzo de 1938, señalaba: "Aprovecho esta ocasión para referirme a una nota oficial que con esta fecha envía este Consulado General al Departamento, llamando la atención de que con la anexión de Austria al Imperio alemán se van a producir grandes fugas de judios, y como es conocido, justamente el judio austríaco es un elemento casi tan malo como el polaco. Creo no equivocarme si le aseguro que hace mucho tiempo he estado preocupado de la cuestión austríaca, porque yo veía venir el nacional-socialismo en ese país y sabia ya que vendrían también de Austria una invasión de solicitudes de judios que desearían radicarse en Chile [...] El judio austríaco por regla general es de descendencia (sic) más o menos directa de judios de la Galicia y de Rusia, es decir, la hez de la raza humana, moralmente y físicamente la más inmunda que darse pueda" ${ }^{\prime 7}$.

La carta más detallada sobre el tema es una enviada por Álvarez de la Rivera a Carlos Errázuriz como respuesta a una consulta que este le había hecho sobre los procedimientos empleados para visar los pasaportes de la población judía. $\mathrm{Al}$ respecto el cónsul general en Hamburgo insistía en quejarse de que desde el Ministerio se le obligaba a conceder visa a una serie de judíos que no tendrían mérito para ello y a los que él se las había negado. Pese a que habría indicado en sus informes "que han ido últimamente ortopédicos, carniceros sastres, etc., con exceso; que esos elementos no pueden ser buenos, que no dominan su profesión" que en otros casos "se ha hecho ver que esos individuos han sido castigados por las autoridades alemanas por haber hecho negocios ilegales" y sin embargo había "tenido que visarles los pasaportes". Respecto al control de capitales, tema sobre el que también consultaba Carlos Errázuriz, Álvarez de la Rivera informaba que "con objeto de evitar la emigración indeseable, en múltiples ocasiones me he mostrado inasequible e intransigente sobre la cuestión del envio de capitales a Chile, solicitándoles, antes de darles la visación, que me comprueben un depósito a su nombre en Chile. Esta exigencia me ha dado un gran éxito en muchos casos. Pero, cuando a un judio no le da la gana hacerlo, se vale de sus influencias en Chile, y, es casi siempre seguro que, al poco tiempo, recibimos un cable del Gobierno ordenándome que de la visa sin poner dificultades". Finalmente concluía lo medular de su informe señalando que: "aqui hacemos todo lo que está en nuestra mano para evitar, en lo posible, la inmigración judia; y si van judios a Chile, no es por culpa nuestra, y si porque se valen de ciertas influencias entre gentes que no quieren comprender este problema"78.

Queda en evidencia con todo esto que la dura posición mantenida por algunos cónsules contra la inmigración judía, no necesariamente era compartida por todas las instancias del Ministerio, lo que explica que finalmente haya llegado a Chile un volumen mucho mayor de inmigrantes de esa raza de lo que era dable

77 Carta de 11 de mayo de 1938, AMRE, vol. 1708. En el mismo sentido se expresaba en carta de 11 de mayo dirigida también a Carlos Errázuriz: "Con el asunto de los expulsados somos cada día más estrictos, tratando que no se filtre ninguno, pues con la anexión de Austria a Alemania, la afluencia de solicitudes de expulsados se ha aumentado en forma abrumadora. Algunos se han atrevido a amenazarme con ciertas influencias y valedores que dicen tener en Chile. Yo sigo invulnerable, contando siempre con el apoyo de Uds." AMRE, vol. 1708.

${ }^{78}$ Carta de 22 de junio de 1938, AMRE, vol. 1708. 
esperar si se consideran sólo las opiniones más extremas antes reseñadas. A ello cooperaba también el hecho de que hubo una serie de cónsules que defenderían una posición más favorable a la inmigración judía.

De acuerdo a lo que se ha señalado en su lugar, la Circular confidencial $N^{\circ}$ 3 de julio de 1937 había establecido que sólo los Consulados Generales de París, Hamburgo y Génova podían visar pasaportes a judíos y ellos estaban a cargo de cónsules -como se ha visto-que tenían perjuicios anti judíos muy acendrados. Más todavía, probablemente por esa razón se los eligió. Contra esa decisión protestaba el Cónsul de Chile en Budapest, quién proponía se le diera ese mismo derecho al Consulado de Viena, con lo que "desaparecerían los rozamientos con Álvarez de la Rivera y por consiguiente nada habría que temer para el futuro". Esta medida se justificaría, "si se considera que justamente es Austria en donde está el mayor número de judios que desean inmigrar"79.

En otro caso el cónsul en La Rochelle, se defendía de las críticas que había recibido del Departamento Consular por haber otorgado visación "ordinaria" a un ciudadano de origen judío, señalando que "el señor Isaac Epelbaum presentó sus certificados de buena conducta, moralidad, médico y vacuna y cartas de recomendación de firmas de Polonia y siendo también de profesión químico, creí que no sería un mal elemento para nuestro pais" $"$.

Una situación similar se daría en el Consulado de Bruselas al conceder visación "ordinaria” a Alfredo Stroch, objetada por el Departamento Consular por ser este de "muy cercana ascendencia israelita". El Cónsul defendería su decisión aduciendo que el afectado era de "raza aria". Más todavía, agregaba: "los antecedentes de policía son buenos; las razones que manifestó para ir a Chile, como ser, la instalación de una industria, su fortuna efectiva, y demás antecedentes que se le pidieran, dieron al Cónsul infrascrito la impresión de que sería un buen elemento para nuestra Patria" $"$.

\section{CONCLUSIÓN}

El gobierno de Arturo Alessandri Palma practicó una política migratoria restrictiva, explicable por las circunstancias económicas que se vivían en Chile, derivada de los efectos de la "gran depresión", y que sería algo común en esos años en buena parte del mundo occidental. Con ella se buscaba proteger al trabajador chileno de la competencia extranjera en un momento en el que la tasa de cesantía seguía siendo muy alta. A poco más de un mes de iniciado su período presidencial tuvo lugar la "Machtergreifung", la toma del poder nacionalsocialista en Alemania, con lo cual se agregó un nuevo problema: miles de judíos empezaron a abandonar Alemania arrancando del antisemitismo nazi. En ese momento afloraron los tradicionales prejuicios anti judíos que existían en ciertos sectores de la sociedad chilena, los que se concretaron en el establecimiento de un sistema de cuotas, que reducía a 50 las familias judías que podían establecerse en Chile

\footnotetext{
${ }^{79}$ Carta de 6 de septiembre de 1938, AMRE, vol. 1708.

${ }^{80}$ Carta de 30 de mayo de 1938, AMRE, vol. 1708.

${ }^{81}$ Carta de 10 de diciembre de 1938, AMRE, vol. 1832.
} 
cada año. De más está decir que esta era una fórmula que no se aplicaba a otro tipo de inmigrantes. Más todavía, al radicalizarse el antisemitismo nazi durante los años 1937 y, sobre todo, 1938, lo que coincidiría con la creciente tendencia de una serie de países a restringir el ingreso de judíos a sus territorios, aumentó la presión de los judíos alemanes y de otros países europeos que iban cayendo en la órbita nazi, por alcanzar América. Ante ello el gobierno chileno -el Ministerio de Relaciones Exteriores, a través de algunas Circulares confidenciales dirigidas al cuerpo consular-, levantó aún más las barreras existentes para frenar la inmigración judía, hasta dar forma a lo que puede considerarse un "estatuto jurídico especial” para la población judía. En la ejecución de esa política por parte del jefe del Departamento Consular del Ministerio y por algunos de los Cónsules chilenos, incluyendo algunos que ocupaban puestos de particular importancia, se nota la presencia de una actitud ante la "cuestión judía", que muestra claras influencias del nuevo antisemitismo que estaba en boga en esos años en la Europa central. La dureza de la terminología usada por parte de los funcionarios diplomáticos chilenos -y sin caer en las exageraciones en las que tiende a incurrir Víctor Farías ${ }^{82}$, porque nos movemos en un período en que el "holocausto" era todavía algo lejano-, excede con mucho lo que eran los "prejuicios anti-judíos, propios de la civilización occidental', que habrían sido típicos también de Chile, según señala Fermandois ${ }^{83}$. Por eso no compartimos la conclusión de este autor cuando señala que "el antisemitismo es una ideología moderna que no ha tenido lugar en Chile" "; $y$, en otro lugar, que "en Chile no hubo verdadero antisemitismo, aunque aqui se ha visto que eran moneda corriente diversas expresiones peyorativas hacia los judios" ${ }^{\prime 2}$. La correspondencia entre el jefe del Departamento Consular y algunos de los Cónsules chilenos en Europa dejan en evidencia que sí lo hubo. Aunque eso no significa afirmar que se estuvieran dispuestos a llegar a los extremos del antisemitismo nazi. Esos horrores eran aún inimaginables.

\section{BiBLIOGRAFÍA}

Material de Archivo

Archivo del Ministerio de Relaciones Exteriores de Chile (AMRE)

Volúmenes 17, 1179, 1647, 1647 A, 1703 A, 1708, 1711 A, 1729 A, 1796, 1832.

Prensa

El Diario Oficial

El Mercurio (Santiago)

La Hora (Santiago)

\footnotetext{
${ }^{82}$ FARÍAS, Los nazis, cit. (n. 74) pp. 181 ss. y Los nazis, cit. (n. 72), II, pp. 77. ss.

${ }^{83}$ Fermandois, Mundo, cit. (n. 37), p. 157.

${ }^{84}$ Ibíd., p. 571.

${ }^{85}$ Fermandois, Abismo, cit. (n. 32), p. 235.
} 
La Nación (Santiago)

La Semana Internacional (Valparaíso)

Fuentes Impresas

Sesiones del Senado (Chile)

Literatura

Brahm, Enrique, Hitler y la Segunda Guerra Mundial, (Santiago de Chile, Editorial Universitaria, 1999)

Brahm García, Enrique, Manuel Montt y la colonización de Llanquihue, en Manuel Montt. Educador, legislador, gobernante y magistrado. Estudios en conmemoración del bicentenario de su nacimiento (1809-2009), (Santiago de Chile, Fundación Manuel Montt, 2009)

Burleigh, Michael, El Tercer Reich. Una nueva historia, (Madrid, Taurus, 2002)

FARÍAS, Víctor, Los nazis en Chile, (Barcelona, Editorial Seix-Barral S.A., 2000)

FARÍAs, Víctor, Los nazis en Chile, Volumen II (Santiago, Editorial Planeta Chilena S.A., 2003)

Fermandois, Joaquín, Abismo y cimiento. Gustavo Ross y las relaciones entre Chile y Estados Unidos 1932-1938, (Santiago, Ediciones Universidad Católica de Chile, 1997)

Fermandois, Joaquín, Mundo y fin de mundo. Chile en la politica mundial 1900-2004, (Santiago, Ediciones Universidad Católica de Chile, 2004)

Friedländer, Saul, El Tercer Reich y los judios (1933-1939). Los años de persecución, (Barcelona, Galaxia Gutenberg. Círculo de Lectores, 2009)

Heim, Sussane, Meyer, Beate, Nicosia, Francis R., (eds.), "Wer bleibt, opfert seine Jahre, vielleicht sein Leben”. Deutsche Juden 1938-1941, (Göttingen, Wallstein Verlag, 2010)

Hilberg, Raúl, La destrucción de los judios europeos (Madrid, Akal, 2005)

Longerich, Peter, Politik der Vernichtung. Eine Gesamtdarstellung der nationalsozialistischen Judenverfolgung (München, Piper Verlag, 1998)

NES-EL, Moshé, Estudios sobre el judaísmo latinoamericano (Buenos Aires-Jerusalem, Ediciones Ultra, Segunda edición, 1987)

Nes-EL, Estudios sobre el judaísmo chileno (Tel Aviv, Ediciones Revista de Oriente y de Occidente, 2009)

Novick, Peter, Nach der Holocaust. Der Umgang mit dem Massenmord, (SttutgartMünchen, DVA, 1999)

PoHL, Dieter, Holocaust. Die Ursachen - das Geschehen - die Folgen (Freiburg, Basel, Wien, Herder, 2000).

VIAL, Gonzalo, Historia de Chile (1891-1973), Volumen IV, La dictadura de Ibáñez (1925-1931), (Santiago, Editorial Fundación, 1996)

WоJAK, Irmtrud, Exil in Chile. Die deutsch-jüdische und politische Emigration während des Nationalsozialismus 1933-1945 (Berlin, Metropol Verlag, 1994) 
